\title{
Tari Glipang sebagai Sarana Peningkatan Konsentrasi Kinestetik Tunagrahita
}

\author{
Arina Restian dan Dian Fitri Nur Aini \\ Universitas Muhammadiyah Malang \\ arina.poenya@gmail.com \\ dianfitri@umm.ac.id
}

\begin{abstract}
Abstrak
Usia sekolah dasar merupakan fase perkembangan awal pada anak untuk mengembangkan kemampuan atau kecerdasannya. Peserta didik memiliki kemampuan berbeda-beda yang dipengaruhi oleh beberapa faktor. Kecerdasan pada manusia khususnya anak usia sekolah dasar meliputi 9 jenis kecerdasan salah satunya adalah kecerdasan kinestetik. Kecerdasan kinestetik pada usia sekolah dasar secara umum berkembang lebih cepat dibandingkan kecerdasan yang lain. Hal ini dikarenakan karakteristik anak usia sekolah dasar cenderung lebih menyukai kegiatan yang bergerak misalnya berlari dan menari. Namun pada anak tunagrahita, kemampuan motoriknya cenderung berkembang lebih lambat dibandingkan dengan anak regular. Tunagrahita memiliki keterbatasan dalam memfokuskan diri pada sesuatu tidak lebih dari setengah jam sehingga mereka sulit berkonsentrasi. Keterlambatan perkembangan kemampuan motorik yang dialami oleh tunagrahita juga berpengaruh terhadap konsentrasi kinestetiknya. Anak cenderung sulit menghafal gerakan-gerakan yang terdapat pada pembelajaran yang mengharuskan mereka bergerak secara bersamaan dengan siswa lain misalnya pada kegiatan senam dan tari. Salah satu upaya yang dapat dilakukan untuk melatih konsentrasi kinestetik pada anak tunagrahita adalah melalui kegiatan menari. Tari memiliki tujuan untuk mengembangkan pribadi peserta didik. Salah satu jenis tarian yang dapat digunakan sebagai sarana terapi tunagrahita adalah Tari Glipang. Tari Glipang merupakan tarian yang berasal dari Probolinggo. Tari Glipang memiliki 13 tahapan yang diterapkan dalam pembelajaran seni yang dapat digunakan sebagai terapi untuk anak tunagrahita. Penerapan gerakan Tari Glipang pada anak grahita dapat membantu mereka meredakan emosi dan berpengaruh pada konsentrasinya. Selain itu, Tari Glipang juga cenderung memiliki gerakan yang fokus ke pengaturan pernapasan. Pengaturan pernapasan yang baik akan melancarkan peredaran darah yag secara langsung berpengaruh pada meningkatnya konsentrasi anak.
\end{abstract}

Kata kunci: tari glipang; konsentrasi kinestetik; tunagrahita

\begin{abstract}
Primary school age is a phase of early development in children to develop their abilities or intelligence. Students have different abilities that are influenced by several factors. Intelligence in humans, especially primary school-age children, includes 9 types of intelligence, one of which is kinesthetic intelligence. Kinesthetic intelligence in elementary school age generally develops faster than other intelligences. This is because the characteristics of primary school-age children tend
\end{abstract}


to prefer activities that move such as running and dancing. But in mentally retarded children, motor skills tend to develop more slowly than regular children. Mentally disabled have a limitation in focusing on something no more than half an hour so that they have difficulty concentrating. Delay in the development of motor skills experienced by mental retardation also affects its kinesthetic concentration. Children tend to find it difficult to memorize the movements found in learning that require them to move together with other students such as gymnastics and dance activities. One effort that can be done to train kinesthetic concentration in mentally retarded children is through dancing activities. Dance has a purpose to develop students personally. One type of dance that can be used as a means of mental retardation therapy is Glipang Dance. Glipang dance is a dance originating from Probolinggo. Glipang dance has 13 stages applied in art learning that can be used as therapy for mentally retarded children. The application of the Glipang Dance movement to children who are grahita can help them relieve emotions and influence their concentration. In addition, Glipang Dance also tends to have movements that focus on breathing arrangements. A good breathing arrangement will improve blood circulation which directly affects the increased concentration of the child.

Keywords: glipang dance; kinesthetic concentration; mental retardation

Anak berkebutuhan khusus memiliki keterbatasan pada dirinya. Salah satu keterbatasan yang dimiliki yaitu mengalami hambatan untuk dapat melakukan berbagai fungsi dalam kehidupannya serta cenderung mengalami kesulitan dalam penyesuaian diri. Anak dengan tingkat tunagrahita sedang memiliki IQ antara 36 sampai 51. Anak tunagrahita cenderung mengalami kelemahan motorik dan gangguan koordinasi sensomotoriknya. Anak tunagrahita memperlihatkan ciri-ciri klinis, seperti downsyndrome, hydrocephalus dan mikrochepalus. Perkembangan kecerdasan anak tunagrahita sedang berbeda dengan anak usia sekolah dasar pada umumnya. Mereka mengalami keterlambatan dalam perkembangan mental dan fisiknya Hal ini dikarenakan mereka memiliki hambatan dalam kinerja otak yang berhubungan dengan hambatan untuk proses penerimaan informasi. Hambatan dalam penerimaan informasi berhubungan dengan kemampuan menerima, memproses dan mengingat.

$$
\text { Perkembangan kinestetik sangat }
$$
mempengaruhi perkembangan motorik anak. Proses perkembangan motorik sejalan dengan bertambahnya usia secara bertahap dan berkesinambungan. Gerakan individu meningkat dari keadaan sederhana, tidak terorganisasi, dan tidak terampil kearah penampilan keterampilan motorik yang kompleks dan terorganisasi dengan baik. Tujuan dari gerakan motorik tersebut pada akhirnya kearah penyesuaian keterampilan menyertai terjadinya proses menua. Kegiatan pembelajaran yang dapat meningkatkan perkembangan kecerdasan kinestetik dapat dilakukan dengan kegiatan menari. Menari merupakan aktivitas yang sangat menyenangkan untuk anak. Menari juga melatih perkembangan fisik, keseimbangan, lifeskill, termasuk kemampuan bertahan dan menjaga diri. 
Tari Glipang merupakan tarian yang memiliki karakteristik menonjol yaitu dalam tariannya terdapat pengolahan nafas. Pengolahan nafas terssebut memiliki arti sebagai ungkapan rasa ketidakpuasan terhadap penjajah pada masa penjajahan Indonesia. Hal ini tercermin pada riasan yang sangar, kostum yang digunakan menggambarkan prajurit sebagai simbol keberanian. Gerakan Tari Glipang menggambarkan semangat yang membara prajurit untuk melawan penjajah. Hal ini berhubungan dengan penerapan pembelajaran tari pada anak tunagrahita yaitu melatih konsentrasi kinestetiknya.

\section{KONSENTRASI}

Dalam proses kehidupan, konsentrasi sangat dibutuhkan oleh manusia agar mampu menjalankan aktivitas secara teratur hingga memperoleh tujuan yang diinginkannya. Namun, untuk beberapa waktu manusia mengalami kendala dengan konsentrasi yang disebabkan oleh faktor internal dan eksternal. Konsentrasi cenderung dibutuhkan oleh peserta didik terutama dalam kegiatan belajar mengajar. Tujuan dari konsentrasi supaya mampu meraih pencapaian dalam pembelajaran.

Konsentrasi adalah pemusatan fungsi jiwa terhadap suatu objek seperti konsentrasi pikiran, perhatian dan sebagainya (Djamarah, 2010). Slameto (2010) mengungkapkan konsentrasi dalam belajar merupakan pemusatan perhatian terhadap mata pelajaran dengan mengenyampingkan semua hal yang tidak berhubungan dengan pelajaran. Konsentrasi merupakan salah satu aspek yang mendukung siswa untuk mencapai prestasi yang baik. Lemahnya konsentrasi akan berdampak pada kegiatan pembelajaran dan kegiatan pribadi siswa.

Konsentrasi dipengaruhi oleh faktor lingkungan (seperti suara, pencahayaan, temperatur dan desain belajar), pergaulan, psikologi dan modalitas belajar. Faktor-faktor inilah yang menentukan siswa dapat memproses setiap informasi. Menurut Slameto (2010) seseorang yang sering mengalami kesulitan untuk berkonsentrasi disebabkan oleh kurang berminat terhadap mata pelajaran yang dipelajari, terganggu oleh keadaan lingkungan (bising, keadaan yang semrawut, cuaca buruk dan lainlain), pikiran kacau dengan banyak urusan/masalah-masalah kesehatan (jiwa dan raga) yang terganggu (badan lemah), bosan terhadap pelajaran/sekolah dan lain-lain.

Berdasarkan beberapa pengertian diatas, dapat disimpulkan bahwa konsentrasi adalah kemampuan memusatkan perhatian pada suatu topik atau persoalan dengan tujuan untuk memperoleh pencapaian yang diinginkan. Secara langsung, konsentrasi dapat meningkatkan kemampuan sesorang dalam semua aktivitasnya.

\section{KINESTETIK}

Kinestetik merupakan kecerdasan yang berhubungan dengan kemampuan seseorang untuk beraktivitas dengan menggerakkan anggota tubuh (Musfiroh, 2010). Anak dengan kecerdasan kinestetik memiliki ciri-ciri: (1) Menonjol prestasinya dibidang olahraga; (2) Senang bergerak dan beraktivitas yang melibatkan gerak fisik; (3) Senang melakukan pekerjaan lapangan; (4) Gemar bongkar pasang mainan. Menurut Yaumi (2012) kecerdasan kinestetik adalah kemampuan 
untuk menggunakan seluruh tubuh dalam mengekspresikan ide, perasaan, dan menggunakan tangan untuk menghasilkan atau mentransformasi sesuatu. Kecerdasan ini mencakup keterampilan khusus seperti koordinasi, keseimbangan, ketangkasan, kekuatan, fleksibilitas dan kecepatan. Kecerdasan ini juga meliputi keterampilan untuk mengontrol gerakan-gerakan tubuh dan kemampuan untuk memanipulasi objek. Komponen inti dari kecerdasan kinestetik adalah kemampuan-kemampuan fisik yang spesifik, seperti koordinasi, keseimbangan, keterampilan, kekuatan, kelenturan, dan kecepatan maupun kemampuan menerima atau merangsang dan hal yang berkaitan dengan sentuhan. Kemampuan ini juga merupakan kemampuan motorik halus, kepekaan sentuhan, daya tahan dan refleks (Yaumi, 2012).

Anak yang memiliki kelebihan dalam kecerdasan kinestetik cenderung mempunyai perasaan yang kuat dan kesadaran mendalam tentang gerakan-gerakan fisik. Anak mampu berkomunikasi dengan baik melalui bahasa tubuh dan sikap dalam bentuk fisik lainnya. Anak juga mampu melakukan tugas dengan baik setelah meniru dan mengikuti tindakannya. Namun, anak yang memiliki kecerdasan ini sering merasa tidak tenang ketika duduk dalam waktu yang relatif lama dan bahkan merasa bosan jika segala sesuatu yang dipelajari atau disampaikan tanpa disertai dengan tindakan yang bersifat demonstrasi (Yaumi, 2012). Kecerdasan kinestetik dapat dikembangkan dengan kegiatan melempar, menangkap, bermain bola, memanjat, bergelantung, menari, estafet, dan lain sebagainya (Musfiroh, 2010).
Stimulasi kecerdasan kinestetik terjadi pada saat anak bergerak. Pada saat bergerak itulah anak berusaha melatih koordinasi otot dan gerak. Stimulasi kinestetik terjadi dalam wilayah-wilayah berikut: a. Koordinasi matatangan dan mata-kaki, seperti menggambar, menulis, memaipulasi objek, menaksir secara visual, melempar, menendang, menangkap. b. Keterampilan lokomotor, seperti berjalan, berlari, melompat, berbaris, meloncat, mencongklak, merayap, berguling, dan merangkak. c. Keterampilan nonlokomotor, seperti membungkuk, menjangkau, memutar tubuh, merentang, mengayun, berjongkok, duduk, berdiri. d. Kemampuan mengontrol dan mengatur tubuh seperti menunjukkan kesadaran tubuh, kesadaran ruang, kesadaran ritmik, keseimbangan, kemampuan untuk mengambil start, kemampuan menghentikan gerak, dan mengubah arah (Catron \& Allen, 2015).

Menurut Gardner (2010) kecerdasan gerak-kinestetik mempunyai lokasi di otak serebelum (otak kecil), basal ganglia (otak keseimbangan) dan motor korteks. Kecerdasan ini memiliki wujud relatif bervariasi, bergantung pada komponenkomponen kekuatan dan fleksibilitas serta domain seperti tari dan olahraga. Menurut Armstrong (2010) kecerdasan kinestetik adalah kecerdasan fisik. Kecerdasan ini mencakup bakat dalam mengendalikan gerakan tubuh dan keterampilan dalam menangani benda. Orang yang mempunyai kecerdasan kinestetik adalah orang-orang cekatan, indra perabanya sangat peka, tidak bisa tinggal diam, dan berminat atas segala sesuatu. Menurut Sujiono (2010) kecerdasan kinestetik adalah suatu kecerdasan di mana anak mampu melakukan gerakan- 
gerakan yang bagus pada saat berlari, menari, membangun sesuatu, semua seni dan hasta karya.

Gardner (2010) mengugkapkan bahwa kecerdasan kinestetik adalah barang siapa yang memiliki kemampuan untuk menggunakan keseluruhan tubuh mereka, atau paling tidak sebagian dari tubuh untuk memecahkan masalah adalah merupakan pengembangan dari kecerdasan kinestetik. Kecerdasan kinestetik adalah kemampuan seseorang untuk menggabungkan antara fisik dan pikiran sehingga menghasilkan gerakan yang sempurna. Artinya kecerdasan kinestetik merupakan koordinasi yang baik antara urat saraf (pikiran) dengan tubuh lainnya. Kecerdasan kinestetik itu merupakan kemampuan untuk menggunakan seluruh bagian badan secara fisik seperti menggunakan tangan, jari-jari, lengan dan berbagai kegiatan fisik lainnya dalam memecahkan masalah, membuat sesuatu, atau dalam menghasilkan berbagai macam produk. Amstrong yang dikutip dalam Sujiono (2010) kecerdasan kinestetik atau kecerdasan fisik adalah suatu kecerdasan dimana saat menggunakannya seseorang mampu atau terampil menggunakan anggota tubuhnya untuk melakukan gerakan seperti berlari, menari, membangun sesuatu, melakukan kegiatan seni atau hasta karya. Komponen inti dari kecerdasan kinestetik adalah kemampuankemampuan fisik yang spesifik, seperti koordinasi, keseimbangan, keterampilan, kekuatan, kelenturan dan kecepatan maupun kemampuan menerima rangsang (proprioceptive) dan hal yang berkaitan dengan sentuhan (tactile dan haptic).
Berdasarkan uraian teori yang telah dikemukakan diatas dapat disimpulkan bahwa kecerdasan kinestetik merupakan kemampuan untuk menggunakan anggota tubuh dalam memecahkan masalah untuk mengekspresikan ide, gagasan yang ditunjukkan melalui praktek, sehingga tujuan dapat tercapai seperti berlari, menari, meloncat dan sebagainya. Kecerdasan kinestetik merupakan kemampuan yang dimiliki oleh manusia untuk menggunakan seluruh anggota tubuh dalam berbagai kegiatan untuk mengasah keterampilan yang dimilikinya.

\section{TARI GLIPANG}

Tari Glipang merupakan tarian yang berasal dari Probolinggo dan mempunyai ciri khas, yaitu tarian dengan mengolah nafas, yang diartikan sebagai ungkapan rasa ketidakpuasan terhadap penjajah pada masa itu. Tercermin pada riasan yang sangar, kostum yang digunakan juga menggambarkan seorang prajurit dan aksesoris yang dipakai (Soedarsono, 2012). (a)Tata Rias. Tata rias pada tarian ini membedakan dengan tarian lainnya, yaitu dengan karakter wajah sangar dan berkumis, dan godek. Untuk pemain musik tidak dirias, tetapi hanya memakai kostum dan odeng. Instrumen pada riasan ini terdiri dari celak, sedo, dan bedak. (b) Busana Penari Glipang. Warna pada busana penari Glipang ini merah dan hitam. Merah yang melambangkan orang Madura yang berani dan tidak takut mati. Sedangkan warna hitam melambangkan kegelapan pikiran yang pada akhirnya tidak bisa mengontrol hawa nafsu. (c) Busana Kiprah. Busana yang dipakai saat ini berwarna merah dan biru, ada juga 
busana warna kuning dan hijau. Aksesoris yang dipakai yaitu rompi, sabuk blandang, sampur, lancor, celana, jarit, keris, gungseng. (d) Busana Baris Glipang. Busana baris terdiri dari ikat kepala (sorban), plat bahu, simbar, baju piyama, samper, dan celana panjang merah. (e) Busana Papakan Glipang. Untuk penari laki, merupakan perpaduan dari busana Kiprah dan Baris, yaitu baju piyama, celana panjang, dan samper. Aksesoris yang dipakai yaitu odeng dan sabuk blandang. Busana perempuan yaitu baju kebaya, stagen, samper, dan aksesoris sunggar bunga, dan gungseng. (f) Busana Pemain Musik. Busana yang dipakai pemain musik ini terdiri dari celana panjang hitam, dengan baju piyama kuning, serta memakai odeng dan sabuk blangdang. g. Alat Musik yang dipakai terdiri dari lima jenis alat musik yang berbeda, yaitu (1) Terbang hadrah yang jumlahnya antara tiga sampai lima terbang hadarah, dengan berbentuk lingkaran dengan diameter $30 \mathrm{~cm}$. Makna dari jumlah terbang yang dipakai yaitu menandakan bahwa rukun islam ada lima, dan jumlah tiga maksudnya adalah rukun islam, rukun iman, dan rukun ikhsan. (2) Serepoh yang menyerupai terompet, yang berfungsi sebagai pengiring irama nada syair yang dibawakan oleh penembang. Makna dari serepoh ini adalah ketika teropmet sangkakala ditiup oleh malaikat, maka dunia ini akan berakhir atau kiamat. Dan tiupan yang kedua bahwa manusia yang ada di alam kubur akan dihidupkan kembali untuk dimintai pertanggungjawabannya selama hidup di dunia. (3) Tongtongan biasanya digunakan oleh banyak orang untuk kegiatan siskamling di desa. Ide muncul dari benak pencipta bahwa tongtongan ini bisa dijadikan alat musik Glipang. Makna alat ini adalah pemberitahuan kepada warga untuk berkumpul. (4) Ketipung berfungsi untuk penanda setiap gerakan dan terdiri dari dua jenis yaitu ketipung laki, dan perempuan. Makna dari alat ini adalah bahwa di dunia ini ada dua hal yang saling berlawanan, misal ada siang dan malam, laki perempuan, ada buruk dan baik. Makna yang lain bahwa seorang perempuan harus taaat kepada suami, dan perempuan tidak boleh menjadi imam. Jumlah pemain ketipung ini ada dua, yaitu penabuh ketipung perempuan dan penabung ketipung laki. (5) Jidor berfungsi sebagai penggema suara pada kesenian Glipang karena suaranya yang menggema. Maknanya adalah melambangkan bahwa tuhan itu ahad, dan agung, sehingga Jidor diletakkan paling atas daripada alat musik yang lain.

\section{RAGAM GERAK TARI GLIPANG SEBAGAI TERAPI TUNAGRAHITA}

Dalam penerapannya, Tari Glipang memiliki 13 ragam gerak yang dapat meningkatkan daya konsentrasi tunagrahita (Agus, 2006). Pertama, gerak siaga yang memiliki beberapa gerakan yaitu posisi kepala tegak lurus menghadap kedepan, posisi tangan kanan di lipat ke dalam dan sejajar dengan bahu, posisi tangan kiri tegak lurus ke samping, posisi kaki kanan maju satu langkah dan serong kedepan, dan posisi tubuh serong ke kanan mengikuti gerakan kaki kanan. Manfaat dari gerak singa adalah gerak tangan memberikan stimulus kepada otak. Gerakan yang dilakukan oleh tubuh tidak hanya bermanfaat bagi kebugaran tubuh, tapi juga 
kebugaran otak, yang akan mengoptimalkan fungsi kerja otak.

Kedua, gerak jalan di tempat yaitu posisi kepala lurus menghadap ke depan, posisi tangan kanan dan kiri dalam posisi siap, kaki kanan dan kiri di angkat secara bergantian, dan posisi tubuh tegak menghadap ke depan. Ketiga, gerak kaki kuda memiliki beberapa gerakan yaitu posisi kepala menghadap ke samping kiri, tangan kanan di lipat ke dalam sejajar dengan dada, posisi tangan kiri lurus dan sedikit menjulang ke atas, posisi ibu jari dan jari telunjuk di lipat membentuk huruf $\mathrm{O}$ dan tiga jari lainnya lurus ke atas, posisi kaki kanan maju ke depan dan serong ke arah kanan diikuti oleh posisi tubuh yang condong ke arah kanan. Ketiga, gerak Jalan di tempat yaitu posisi kepala lurus menghadap ke depan, posisi tangan kanan dan kiri dalam posisi siap, kaki kanan dan kiri di angkat secara bergantian, dan posisi tubuh tegak menghadap ke depan. Gerakan tubuh dan kaki bermanfaat bagi kecerdasan kinestetik (Suyadi, 2014).

Kelima, gerak lesung pipi yaitu posisi kepala menghadap ke samping kiri, posisi tangan kanan berada di pinggang, posisi tangan kiri berada di pipi dengan jari telunjuk membentuk angka 1, posisi kaki kanan serong maju ke kanan, dan posisi tubuh serong menghadap ke kiri. Kelima, gerakan menyerang lawan yaitu posisi kepala fokus menghadap ke depan, posisi tangan kanan berada di depan perut, posisi tangan kiri berada di belakang tangan kanan, posisi jari telunjuk kanan dan kiri membentuk huruf L dan tiga jari lainnya di lipat ke dalam, posisi kaki kanan maju ke depan, dan posisi tubuh menghadap ke depan. Keenam, gerakan menyerang lawan yaitu posisi kepala fokus menghadap ke depan, posisi tangan kanan berada di depan perut, posisi tangan kiri berada di belakang tangan kanan, posisi jari telunjuk kanan dan kiri membentuk huruf L dan tiga jari lainnya di lipat ke dalam, posisi kaki kanan maju ke depan, dan posisi tubuh menghadap ke depan.

Kedelapan, gerak algojo yaitu posisi kepala menghadap ke samping kiri dengan mata melirik ke depan, posisi tangan kanan dan kiri membentuk kepalan, posisi tangan kanan berada di depan perut, posisi tangan kiri berada di atas kepala, dan posisi kaki kanan serong ke depan, dan posisi badan menghadap serong ke arah kiri. Kedelapan, gerak algojo silang yaitu posisi kepala menghadap ke depan, posisi tangan kanan dan kiri membentuk kepalan, posisi tangan kanan di lipat ke atas, posisi tangan kiri di lipat ke bawah dan ke arah dalam, posisi kaki kanan serong ke kanan, dan posisi tubuh menghadap ke kanan. Kesepuluh, gerak serangan yaitu posisi kepala menghadap ke depan, posisi tangan kanan dan kiri membentuk kepalan, posisi tangan kanan lurus ke depan dan posisi tangan kiri sejajar dengan pinggang, dan posisi badan menghadap ke depan.

Kesebelas, gerak pinguin, posisi kepala lurus ke depan, posisi tangan dalam posisi siap dan seperti pinguin, kedua kaki sedikit dibuka, dan posisi tubuh tegap. Sebelas, gerak melambai kesamping yaitu posisi kepala menghadap ke depan, posisi tangan kanan diangkat sejajar kepala kemudian di putarputar, sedangkan posisi tangan tangan lainnya berada di depan dada kemudian di putarputar. Posisi kaki kanan diangkat dan posisi tubuh menghadap ke depan. Tiga belas, 
gerakan penghormatan yaitu posisi kepala menghadap ke depan, kedua tangan berada didepan dada dan direkatkan menjadi satu, bahu sedikit di buka, kaki kanan maju kedepan, dan posisi tubuh menghadap ke depan.

\section{TUNAGRAHITA}

Menurut Sutjihati Soemantri (2006: 106) bahwa tunagrahita ringan disebut juga moron atau debil. Kelompok ini memiliki IQ antara 68 - 52 menurut skala Binet, sedangkan menurut skala Wischler (WISC) memiliki IQ 69 - 55. Tunagrahita kelompok ini dapat belajar membaca menulis dan berhitung sederhana. Dengan bimbingan dan pendidikan yang baik anak tunagrahita ringan dapat dididik menjadi tenaga kerja semiskilled. Seperti pekerjaan laundry, pertanian, peternakan, pekerjaan rumah tangga, bahkan jika dilatih dan dibimbing dengan baik dapat bekerja di pabrik- pabrik dengan sedikit pengawasan.

Menurut Jazuli (2011) karakteristik anak dengan hendaya perkembangan (tunagrahita), meliputi hal-hal sebagai berikut; (1) Mempunyai dasar secara fisiologis, sosial dan emosional sama seperti anak-anak yang tidak menyandang tunagrahita; (2) Selalu bersifat eksternal locus of control sehingga mudah sekali melakukan kesalahan (expectancy for filure); (3) Suka meniru perilaku yang benar dari orang lain dalam upaya mengatasi kesalahankesalahan yang mungkin dilakukannya outerdirectedness); (4) Mempunyai perilaku yang tidak dapat mengatur dirinya sendiri; (5) Mempunyai permasalahan berkaitan dengan perilaku sosial (social behavioral); (6)
Mempunyai masalah berkaitan dengan karakteristik belajar; (7) Mempunyai masalah dalam bahasa pengucapan; (8) Mempunyai masalah dalam kesehatan fisik; (9) Kurang mampu untuk berkomunikasi; Mempunyai kelainan pada sensori dan gerak; (11) Mempunyai masalah berkaitan dengan psikiatrik, adanya gejala-gejala depresif .

Anak tunagrahita ringan tidak mampu melakukan penyesuaian sosial secara independen. Pada umumnya tidak mengalami gangguan fisik. Bila dikehendaki mereka ini masih dapat bersekolah di sekolah anak kesulitan belajar, ia akan dilayani pada kelas khusus dengan guru dari pendidikan luar biasa. Menurut Mumpuniarti (2007) anak tunagrahita ringan adalah anak yang tingkat kecerdasannya berkisar 50-70, mampu menyesuaikan diri pada lingkungan sosial yang lebih luas dan mampu melakukan pekerjaan setingkat semi-terampil.

Mumpuniarti (2007) menjelaskan karakteristik anak tunagrahita ringan antara lain: 1) kesulitan dalam akademik, 2) miskin dalam perbendaharaan bahasa serta perhatian dan ingatannya lemah. Karakteristik anak tunagrahita secara umum mengalami kelemahan dalam pemikiran, namun di sisi lain kemampuan yang lain masih dapat dikembangkan khususnya yang berkaitan dengan bidang keterampilan. Menurut Rini Hidayani (2007) mengemukakan bahwa untuk bidang pekerjaan, mereka mampu melakukan pekerjaan sederhana, menyelesaikan tugas yang diberikan dan juga mengatur ruang.

Karakteristik yang tidak jauh berbeda dengan anak normal ini yang menyebabkan tidak terdeteksi sejak awal sebelum masuk 
sekolah. Anak baru terdeteksi ketika mulai masuk sekolah baik di tingkat pra sekolah maupun sekolah dasar. Terdeteksi itu dengan menampakkan ciri ketidak mampuan di bidang akademik, maupun kemampuan pekerjaan di sekolah yang membutuhkan keterampilan motorik. Anak tunagrahita ringan adalah anak yang memiliki IQ di bawah normal, mereka masih memiliki potensi untuk berkembang dalam bidang membaca, menulis dan berhitung sederhana, mereka juga dapat dididik keterampilan dalam kehidupan sehari-hari, serta dapat diberikan latihan-latihan ketrampilan sederhana yang memerlukan program khusus dan bimbingan khusus, agar nantinya dapat berkembang potensinya seoptimal mungkin untuk bekal hidup mandiri di masyarakat.

Berdasarkan pendapat tentang karakteristik anak tunagrahita ringan di atas dapat ditegaskan bahwa karakteristik anak tunagrahita ringan antaralain kecerdasan anak antara 50-70, kemampuan bahasa rendah, tidak dapat berfikir secara abstrak, dapat melakukan pekerjaan yang sederhana. Dengan karakteristik yang dimiliki anak tunagrahita tersebut, memungkinkan untuk dapat mengikuti pembelajaran keterampilan memasang payet. Kemampuan anak tunagrahita yang terbatas pada kognitif masih memiliki kemampuan yang dikembangkan yaitu motoriknya. Kemampuan motorik anak tunagrahita ringan pada umumnya tidak berbeda dengan anak normal, maka untuk melakukan pembelajaran keterampilan tidak bermasalah. Keterampilan memasang payet sebagian besar hanya menggunakan tenaga tangan maka akan lebih mudah untuk dilakukan oleh anak tunagrahita.

\section{TARI GLIPANG SEBAGAI SARANA PENINGKATAN KONSENTRASI KINESTETIK TUNAGRAHITA}

Seni tari memiliki banyak manfaat. diantaranya dikemukakan oleh yang menyatakan bahwa tujuan tari bagi anakanak dari segala usia dan kondisi sosial adalah: 1) membimbing mereka dalam berbagai aktivitas fisik yang bervariasi guna mengenal secara sadar tentang fungsi dan hubungan bagian-bagian yang bergerak pada tubuh mereka; 2) memperkenalkan konsep ruang, waktu dan tenaga dalam hubungannya dengan gerak tubuh mereka baik secara perseorangan maupun bersama orang lain; 3) mendorong timbulnya kebanggaan dalam upaya mengembangkan kontrol dan keterampilan gerak khusus (yang dramatik dan ekspresif); 4) mengusahakan situasi tertentu pada mereka agar dapat mengambangkan imajinasi dengan cara menari, seperti dalam hubungannya dengan teman, saudara, tetangga, orang yang berbeda usia dan kebudayaan, dapat merasakan dan memberi reaksi; 5) mendorong kreativitas mereka dalam eksplorasi serta mendiskusikan ideide, meningkatkan diri dan apresiasi terhadap gagasan maupun prestasi orang lain. Dengan menari akan muncul situasi kritis dan penuh arti, karena perasaan lebih bisa dimengerti dan dikontrol, dan kontrol diri bisa diperluas menjadi kontrol keseimbangan diri secara alamiah (Mary, 2009).

Selain itu seni tari juga bermanfaat bagi perkembangan mental anak. Hal ini 
seperti dikemukakan oleh Delphi (2005) yang menyatakan bahwa pembelajaran seni tari memiliki fungsi untuk membantu pertumbuhan dan perkembangan anak. Peranan seni tari antara lain untuk meningkatkan perkembangan fisik, mental, dan estetis, memberi sumbangan ke arah sadar diri, membina imajinasi kreatif, dan membantu dalam pemecahan masalah. Pembelajaran tari disesuaikan dengan tingkat perkembangan anak berdasarkan pada teori perkembangan dari Piaget. Piaget lebih menekankan kepada pengenalan lingkungan yang ada di sekeliling kehidupan peserta didik.

Tari Glipang memiliki beberapa manfaat terutama untuk tunagrahita yaitu meningkatkan rasa percaya diri dan dapat digunakan sebagai pengontrol emosi, sebagai pengontrol kecepatan berbicara sehingga mudah dipahami oleh orang lain, mengurangi perilaku mengganggu teman, mampu berkonsentrasi dalam pembelajaran, mengembangkan kemampuan bersosialisasi. Penerapan Tari Glipang dapat dilakukan secara bertahap dan intensif kepada anak tunagrahita. Gerakan-gerakan yang dilakukan juga disesuaikan dengan usia anak sehingga lebih mudah diaplikasikan.

\section{PENUTUP}

Tunagrahita cenderung mengalami keterbatasan dalam mengatur emosi serta aktivitasnya dikarenakan faktor internal dan eksternal. Ketidakmampuan tersebut berdampak pada rendahnya tingkat konsentrasi kinestetik yang dimiliki oleh anak tunagrahita. Salah satu alternatif yang dapat digunakan sebagai terapi peningkatan daya konsentrasinya yaitu dengan menggunakan tarian. Tarian menerapkan beberapa gerakan yang secara umum dapat meningkatkan daya konsentrasi kinestetik tunagrahita. Tari Glipang adalah jenis tarian yang mengandung unsur-unsur pelatihan pernapasan sehingga dapat digunakan sebagai terapi multisensory untuk anak tunagrahita. Selain itu, Tari Glipang juga memiliki filosofi tari yang didalamnya berisi pesan keberanian dan penuh semangat sehingga dapat meningkatkan kemenarikan bagi tunagrahita dalam menerapkannya. Tari Glipang memiliki 13 gerakan yang dapat memicu daya konsentrasi kinestetik tunagrahita. Gerakan tersebut terdiri dari gerak siaga, gerak kakik kuda, gerak jalan di tempat, gerak lesung pipi, gerak kuda-kuda, gerakan menyerang lawan, gerak algojo, gerak algojo silang, gerak serangan, gerak pinguin, gerak melambai ke atas, gerak melambai kesamping, dan gerakan penghormatan.

\section{DAFTAR PUSTAKA}

Armstrong, Thomas. (2010). 7 Kind of Smart (Menemukan dan Meningkatkan Kecerdasan Anda berdasarkan Teori Multiple Intelegence. Jakarta: Gramedia Pustaka Utama

Catron, C.E. \& Allen, J. (2015). Early Childhood Curriculum A Creative-Play Model. New Jersey: Merill, PrenticeHall.

Delphie, Bandi. (2005). Program Pembelajaran Individual Berbasis Gerak Irama. Bandung: Pustaka Bani Quraisy

Djamarah, Syaiful Bahri, dkk. (2010). Strategi Belajar Mengajar. Jakarta: Rineka Cipta. 
Gardner, Howard. (2010). Frame of Mind the Theory of Multiple Intelligence. Amerika: basic books

Hidayani, Rini. (2007). Psikologi Perkembangan Anak. Jakarta: Universitas Terbuka

Hidayat, Agus. (2006). Seni Tari Glipang Probolinggo Analisis Bentuk, Fungsi dan Makna dengan Pendekatan Folklor. Skripsi. Malang: FKIP UMM.

Jazuli. (2011). Paradigma kontekstual Pendidikan Seni. Unesa University Press. Semarang

Joyce, Mary. (2009). First Steps in Teaching Creative Dance to Children. USA: Mayfield Publishing Company.

Mumpuniarti. (2007). Pendekatan Pembelajaran Bagi Anak Hambatan Mental. Yogyakarta: Kanwa Publisher.

Musfiroh, Tadkiroatun. (2010). Pengembangan Kecerdasan Majemuk. Jakarta: Universitas Terbuka.

Slameto. (2010). Belajar dan Faktor yang mempengaruhinya. Jakarta: Rineka Cipta.

Soedarsono. (2012). Pengantar Komposisi Tari. Yogyakarta: ASTI.

Sujiono, Yuliani Nuraini, dkk. (2010). Bermain Kreatif Berbasis Kecerdasan Jamak. Jakarta: Indeks

Sujiono, Yuliani Nurani dan Sujiono, Bambang. (2010). Bermain Kreatif Berbasis Kecerdasan Jamak. Jakarta: PT Indeks

Yaumi, Muhammad. (2012). Pembelajaran Berbasis Multiple Intelligences. Jakarta: Dian Rakyat 